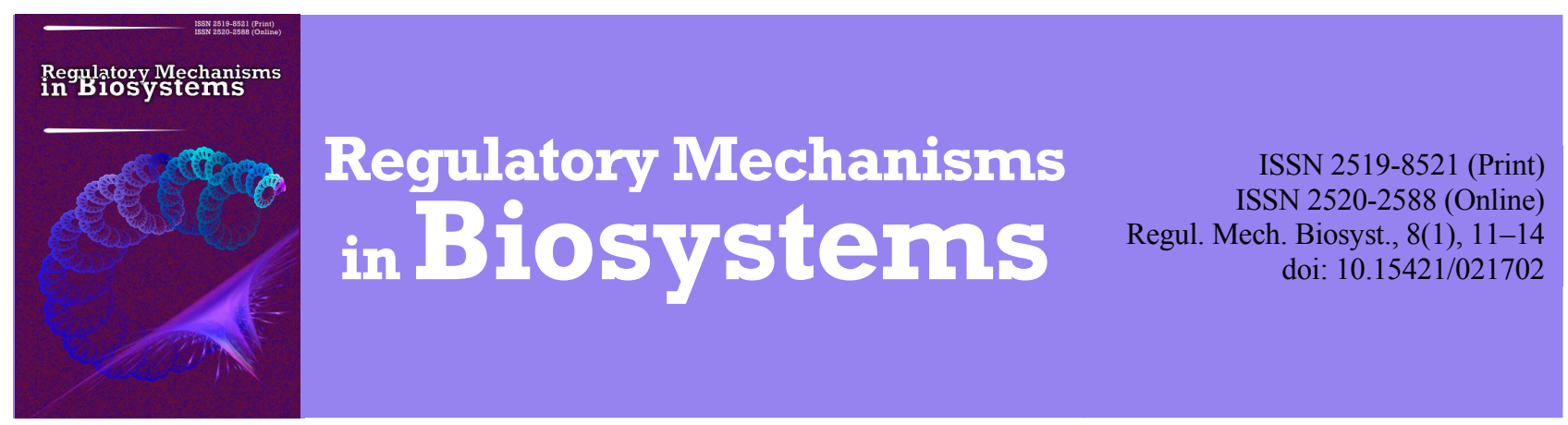

\title{
Biochemical composition of urine in rats with developed Guerin's carcinoma and administration of cisplatin
}

\author{
A. N. Naumenko, M. V. Gorelaya, S. O. Babiy \\ Oles Honchar Dnipropetrovsk National University, Dnipro, Ukraine
}

Article info

Received 20.12.2016

Received in revised form

15.01.2017

Accepted 22.01.2017

Oles Honchar Dnipropetrovsk National University,

Gagarin ave., 72

Dipro, 49010, Ukraine

Tel.: +38-067-28-34-569

E-mail: gorelaya@ukr.net

\begin{abstract}
Naumenko, A. N., Gorelaya, M. V., \& Babiy, S. O. (2017). Biochemical composition of urine in rats with developed Guerin's carcinoma and administration of cisplatin. Regulatory Mechanisms in Biosystems, 8(1), 11-14. doi: $10.15421 / 021702$

The kidneys are very sensitive to the action not only of exogenous chemicals but also the action of compounds of endogenous origin, produced by changes in the normal metabolic processes and the development of various pathologies. Thus, tumour development has a significant impact on overall homeostasis of the body. Research into the condition of the kidneys subject to growth of tumours when cisplatin is administered is a major issue in both medical and biochemical aspects. We investigated the renal function, electrolyte composition of the blood and urinary excretion of electrolytes and individual plasma osmolarity in models of tumour growth in rats subject to introduction of cisplatin. We found that development of Guerin's carcinoma T8 and the administration of cisplatin causes kidney damage in rats. This leads to an increase in the relative weight of the kidneys, proteinuria, and changes in activity of $\gamma$-glutamyltransferase and lactate dehydrogenase in the kidney homogenate and urine, lower relative reabsorption and glomerular filtration. The development of Guerin's carcinoma and administration of cisplatin in the blood and urine of rats led to a decrease in diuresis per minute by $20-60 \%$, creatinine clearance by $50-70 \%$ and reduction in the relative water reabsorption in the renal tubules to $26 \%$ compared with the control. The administration of cisplatin led to a threefold increase in the concentration of protein, twofold increase in the concentration of albumin and sevenfold increase in the concentration of glucose in the rats'urine. In the case of rats with lesions and renal diseases (including different types of tumours) a reduction in the output of urine per minute, creatinine clearance and water reabsorption in the renal tubules was observed, indicating significant damage to the concentration and filtration functions of the kidneys. Tumour growth led to the development of hypokalemia, hyponatremia and hypochloridemia, which are major and early signs of acute renal failure. The introduction of cisplatin led to damage to the kidneys and partly normalized these indicators, as evidenced by biochemical and morphological studies. Our study shows that there is a pressing need for use of drugs which protect the kidneys when cisplatin is administered.
\end{abstract}

Keywords: Guerin's carcinoma; electrolytes; biochemical markers; acute renal failure

\section{Біохімічний склад сечі щурів в умовах розвитку карциноми Герена та введення цисплатину}

\author{
А. Н. Науменко, М. В. Горіла, С. О. Бабій \\ Дніпропетровський національний університет імені Олеся Гончара, Дніпро, Украӥна
}

Нирки чутливі до дії не лише екзогенних хімічних сполук, а і до дії речовин ендогенного походження, що утворюються за зміни перебігу нормальних метаболічних процесів і появи різних патологій. Розвиток пухлини має значний вплив на гомеостаз у цілому організмі. Дослідження стану нирок за пухлинного росту та уведення цисплатину - важливе питання медицини та біохімії. Вивчено функціональний стан нирок, електролітичний склад крові та сечі, екскрецію окремих електролітів та осмолярність плазми крові в моделі пухлинного росту у щурів під час уведення цисплатину. Розвиток карциноми Герена Т8 та уведення цисплатину зумовлювали пошкодження нирок щурів. Це спричинювало збільшення відносної ваги нирок, протеїнурію, зміни активності $\gamma$-глутамілтрансферази та лактатдегідрогенази в гомогенаті нирок і сечі, зниження відносної реабсорбції та клубочкової фільтрації. У результаті розвитку карциноми Герена та уведення цисплатину в крові та сечі щурів відбувалося зниження хвилинного діурезу на 20-60\%, кліренсу креатиніну - на 50-70\%, зниження відносної реабсорбції води в ниркових канальцях - до $26 \%$ порівняно з контролем. Уведення цисплатину викликало збільшення концентрації загального білка втричі, альбуміну - удвічі та збільшення кількості глюкози в сечі щурів усемеро. Під час уражень і захворювань нирок (у тому числі під час розвитку пухлин різних типів) у щурів спостерігали зниження хвилинного діурезу, кліренсу креатиніну, реабсорбції води в ниркових канальцях, що свідчило про значні порушення концентраційної та фільтраційної функцій нирок. Пухлинний ріст спричинював розвиток гіпокаліємії, гіпонатріємії та гіпохлоремії, як однієї з головних і ранніх ознак гострої ниркової недостатності. Уведення цисплатину викликало 
ураження нирок і нормалізувало ці показники, що підтверджувалося біохімічними та морфологічними дослідженнями. Виявлено нагальну необхідність застосування у подальшому нефропротекторних препаратів під час уведення цисплатину.

Ключові слова: карцинома Герена; електроліти; біохімічні маркери; гостра ниркова недостатність

Вступ

Низка факторів зумовлює особливу схильність ниркових канальців та інтерстицію до пошкодження токсинами. Хоча на нирки припадає менше $1 \%$ маси тіла, у середньому вони отримують приблизно 20\% крові 3 хвилинного об'єму серця та $90 \%$ або більше з цього вельми значного ниркового кровотоку припадає на коркову речовину нирок. Тому вплив токсинів, що циркулюють у крові, на канальці та інтерстицій коркової речовини нирок набагато сильніший у кількісному відношенні, ніж на більшість інших тканин (Han, 2008; Bazaev, 2013; Moskvina, 2013).

Одними 3 найчутливіших органів щодо впливу не лише екзогенних хімічних сполук, а також речовин ендогенного походження, що виникають під час зміни нормальних метаболічних процесів i розвитку різних патологій, безумовно виявляються нирки. У разі канцерогенезу поява пухлини має значний вплив на гомеостаз у цілому організмі. Під час застосування протипухлинних препаратів змінюється функціонування нирок. За введення цисплатину можливі порушення функції нирок, зовнішніми проявами яких будуть нудота, блювання, втрата апетиту, запаморочення, шум у вухах, зниження слуху, анафілактичні (алергічні) реакції, лейкопенія, тромбоцитопенія, анемія (Fink, 2000). Ураження нирок і сечовивідної системи під час застосування цисплатину спричинюе порушення процесів сечоутворення: рідко спостерігаються такі ознаки як дизурія, гематурія, затримання сечовипускання, ниркова недостатність, олігурія, інтерстиціальний нефрит (Mandic, 2003; Martins, 2008; Loh, 2009; Nosov, 2012).

Діагностика захворювань нирок базується на аналізі сечі, тому що під час ураження нирок і за наявності запальних процесів вона змінює свої характеристики. Застосування цитостатиків викликає порушення процесів функціонування нирок (Kapoor, 2001; Darmon, 2006; Kelland, 2007). Дослідження стану нирок за умов пухлинного росту та уведення цисплатину важливе питання медицини та біохімії. Вивчення впливу протипухлинних ліків на біохімічні маркери функціонального стану нирок дозволить розробити ефективні схеми лікування, а також буде корисним під час дослідження біохімічних ефектів нових сполук із протипухлинною дією.

Це дослідження виконане для з'ясування змін біохімічного складу крові та сечі, функціонального стану нирок за умов пухлинного росту та введення розчину цисплатину (cis- $\mathrm{PtCl}_{2}\left(\mathrm{NH}_{3}\right)_{2}$, або цис-діамінодихлороплатини (II)).

\section{Матеріал і методи досліджень}

Експерименти проводили на щурах лінії Wistar вагою 100 150 г, яким перещеплювали підшкірно у ліву задню лапу карциному Герена $\left(\mathrm{T}_{8}\right)(20 \%$ суспензію клітин у фізіологічному розчині). Штам клітин отримано з Інституту експериментальної патології, онкології та радіобіології ім. Р. Є. Кавецького НАН України. Використано кров і сечу щурів із карциномою Герена. Тварин поділили на дослідні групи по 7-8 щурів у кожній: група I - інтактні тварини, група II - тварини 3 карциномою Герена $\mathrm{T}_{8}$, група III - тварини 3 карциномою Герена $\mathrm{T}_{8}$, яким одноразово вводили розчин цисплатину. Як дослідні маркери використано концентрацію креатиніну в крові та сечі, а також загального білка, калію, натрію та хлору у крові. Сечу дослідних тварин збмрали вранці, натще, за умов індукованого діурезу з використанням $1 \%$ водного навантаження відповідно до методики, описаної Берхіним та Івановим у 1972 році (Berkhin, 1972).

Після декапітації тварин видаляли нирки. Органи промивали від залишків крові охолодженим фізіологічним розчином, висушували на паперовому фільтрі, зважували, одну нирку подрібнювали ножицями. Стакан гомогенізатора з тканиною розміщували на баню з льодом. Готували $10 \%$ гомогенат на $0,3 \mathrm{M}$ сахарозі з 0,001 М ЕДТА. Подрібнювали тканину шляхом багаторазового обертання пестика у ручному гомогенізаторі Даунса упродовж 1 хв. Отриманий гомогенат центрифугували

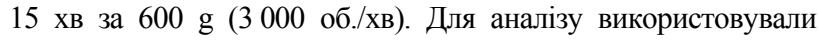
надосадову рідину.

Концентрацію загального білка визначали за допомогою діагностичних наборів реактивів виробництва «Філісіт-Діагностика» (Україна, Дніпро). Метод полягає у реакції білків із пірогалоловим червоним / молібдатом з утворенням забарвленого комплексу. Інтенсивність забарвлення реакційного розчину пропорційна концентрації білків в аналізованому розчині (Berkhin, 1972). Креатинін визначали за допомогою діагностичних наборів реактивів виробництва «Філісіт-Діагностика». Метод полягає у реакції пікринової кислоти 3 креатиніном і утворенні в лужному середовищі продукту жовтого-червоного кольору (похідне 2,4,6-три-нітроциклогексадієну). Інтенсивність забарвлення дослідного розчину пропорційна концентрації креатиніну у пробі. У сироватці крові креатинін досліджено після депротеїнування розчином трихлороцтової кислоти, у сечі - після розведення (Berkhin, 1972).

Концентрацію глюкози визначали глюкозооксидазним методом за допомогою діагностичного набору реактивів виробництва «Філісіт-Діагностика» (Україна, Дніпро). Принцип методу полягав у здатності глюкози окиснюватись киснем повітря до глюконової кислоти та перекису водню, що за присутності пероксидази реагував із фенолом і 4-амінофеназоном 3 утворенням хіноніміну червоно-фіолетового забарвлення, що визначалось фотометрично (Berkhin, 1972).

Швидкість клубочкової фільтрації за кліренсом ендогенного креатиніну (CCr) визначали за пробою Реберга - Тареєва. Концентрацію неорганічного фосфору визначали за допомогою діагностичного набору реактивів виробництва «ФілісітДіагностика». Метод полягає у реакції неорганічних фосфатів iз молібденовою кислотою та утворенні в сильнокислому середовищі фосфомолібденової кислоти, що відновлювалася за присутності заліза (II) у молібденову синь. Інтенсивність забарвлення дослідного розчину пропорційна концентрації неорганічного фосфору у пробі (Berkhin, 1972).

Концентрацію хлоридів визначали фотометричним методом за допомогою діагностичного набору реактивів виробництва «Філісіт-Діагностика». Метод базується на здатності хлорид-іонів у сильнокислому середовищі вивільняти з родоніту ртуті (II) іон родоніту, що реагував 3 іонами заліза (III) 3 утворенням забарвленого продукту. Інтенсивність забарвлення утвореного роданіду заліза пропорційна концентрації іонів хлориду у пробі (Berkhin, 1972).

Концентрацію калію визначали турбідиметричним методом без депротеїнізації за допомогою діагностичного набору реактивів виробництва «Філісіт-Діагностика». Метод базується на взаємодії іонів тетрафенілбората у лужному середовищі з утворенням стабільної суспензії. Мутність суспензії, яку вимірювали за довжини хвилі 578 нм, пропорційна концентрації іонів калію у дослідному зразку (Berkhin, 1972).

Результати опрацьовували статистично, використовуючи однофазний дисперсійний аналіз (ANOVA). Вірогідними вважали відмінності між зразками за $\mathrm{P}<0,05$. У таблицях наведено $\mathrm{x} \pm \mathrm{SD}$.

\section{Результати та їх обговорення}

За розвитку пухлини (група $\mathrm{T}_{8}$ ) встановлене збільшення хвилинного діурезу в 1,6 раза, порівняно з контрольною групою (табл. 1). Уведення цисплатину знижувало хвилинний 
діурез в 1,8 раза порівняно з контролем. Тобто у щурів-пухлиноносіїв за введення розчину цисплатину відмічено олігурію, що свідчило про ознаки токсичної дії цього протипухлинного препарату, показаної у літературному огляді (Kelland, 2007).

За розвитку пухлини та введення цисплатину відмічали збільшення концентрації креатиніну в крові в 2,6 та 1,4 раза відповідно, порівняно з контролем (табл. 1).

Такі зміни демонстрували накопичення в організмі азотумісних метаболітів унаслідок їх посиленої продукції та порушення процесів фільтрації в нирках.

Відповідно до зростання вмісту креатиніну в крові пухлинний ріст і введення цисплатину викликали збільшення цього показника в сечі. Встановлене збільшення креатиніну в 1,3 раза в групі $\mathrm{T}_{8}+\mathrm{cPt}$ порівняно з контролем.

Для визначення фільтраційної здатності нирок враховували співвідношення концентрації креатиніну в крові та сечі, розраховували кліренс креатиніну. Під час визначення концентрації креатиніну та кліренсу креатиніну в групі $\mathrm{T}_{8}$ встанов лено їі зменшення на $10 \%$ порівняно з контролем. За введення цисплатину значення кліренсу креатиніну зменшилось в 1,6 раза порівняно 3 контролем. Таким чином, пухлинний ріст та введення цисплатину здатні порушувати фільтраційну функцію нирок. За умов розвитку пухлини рівень загального білка та альбуміну в сечі збільшувався в 1,3 та 1,7 раза відповідно, порівняно з контролем (табл. 2).

\section{Таблиця 1}

Біохімічні маркери функціонального стану нирок у щурів із пухлиною $(\mathrm{n}=8)$

\begin{tabular}{|c|c|c|c|}
\hline \multirow{2}{*}{$\begin{array}{l}\text { Групи } \\
\text { тварин }\end{array}$} & \multicolumn{2}{|c|}{ Креатинін, мкмоль/л } & \multirow{2}{*}{$\begin{array}{c}\text { Кліренс креатиніну, } \\
\text { мкл/хв на } 100 \text { г }\end{array}$} \\
\hline & кров & сеча & \\
\hline Контроль & $237,3 \pm 16,9$ & $5,61 \pm 1,04$ & $0,816 \pm 0,465$ \\
\hline $\mathrm{T}_{8}$ & $623,5 \pm 35,5^{*}$ & $4,62 \pm 0,71$ & $0,712 \pm 0,341$ \\
\hline $\mathrm{T}_{8}+[\mathrm{cPt}] \mathrm{s} \ln$ & $165,9 \pm 25,5$ & $7,44 \pm 1,14 *$ & $0,544 \pm 0,311^{*}$ \\
\hline
\end{tabular}

Примітка: \# - $\mathrm{P}<0,05$ порівняно 3 контролем; * $-\mathrm{P}<0,05$ порівняно $3 \mathrm{~T}_{8}+[\mathrm{cPt}] \sin$.

\section{Таблиця 2}

Біохімічні маркери ниркового ушкодження

у щурів із карциномою, чутливою до дії цисплатину $(\mathrm{n}=8)$

\begin{tabular}{llcc}
\hline Групи тварин & Білок, мкг/мл & Альбумін, ммоль/л & Глюкоза, ммоль/л \\
\hline Контроль & $0,232 \pm 0,012$ & $0,231 \pm 0,012$ & $0,741 \pm 0,511$ \\
T8 & $0,392 \pm 0,024$ & $0,391 \pm 0,051 \#$ & $0,142 \pm 0,031 \#$ \\
T8+[cPt] $\ln$ & $0,642 \pm 0,121 \#$ & $0,464 \pm 0,091 \#$ & $5,831 \pm 0,514 \#$ \\
\hline
\end{tabular}

Примітка: * - $\mathrm{P}<0,05$ порівняно $3 \mathrm{~T}_{8}+[\mathrm{cPt}] \sin$; \# - $\mathrm{P}<0,05$ порівняно 3 контролем.

За введення цисплатину щурам-пухлиноносіям встановлено, що концентрація загального білка в сечі збільшилась в 2,8 раза, а альбуміну - в 2,0 раза порівняно з контролем. Такі зміни можуть бути викликані як порушенням білкового обміну в організмі за дії патологічних факторів, так і внаслідок пошкодження нефронів, що викликає фільтрацію 3 кровотоку білків високої молекулярної маси та зумовлює порушення реабсорбції з первинної сечі.

Ці дані співвідносяться з результатами дослідження рівня глюкози в сечі. Під час визначення концентрації глюкози в сечі встановлено, що в групі $\mathrm{T}_{8}$ iі концентрація зменшилась у 5,3 раза порівняно з контролем. Це могло бути наслідком розвитку гіпоглікемічного стану у дослідних щурів, викликаного інтенсивним пухлинним ростом.

За введення цисплатину концентрація глюкози в сечі збільшилась в 7,8 раза порівняно з контролем. Глюкозурія виступає характерною ознакою цисплатинової нефропатії (Huphreys, 2005). Такі зміни, вірогідно, викликані ушкодженням ниркових канальців токсичними метаболітами цисплатину, що порушує процеси реабсорбції низькомолекулярних сполук.

Отже, пухлинний ріст та цисплатин мають виражений нефротоксичний ефект, який проявляється у порушенні процесів канальцевої реабсорбції та клубочкової фільтрації.
За розвитку пухлини активність ЛДГ у сечі зменшилась удвічі порівняно 3 контролем (табл. 3).

\section{Таблиця 3}

Активність ЛДГ і ГТП у щурів із карциномою, чутливою до дії цисплатину $(\mathrm{n}=8)$

\begin{tabular}{lcc}
\hline \multicolumn{1}{c}{ Групи тварин } & ЛДГ $\times 10^{-3}, \mathrm{MO} / л$ & ГТП, МО/л \\
\hline Контроль & $20,4 \pm 7,79$ & $0,90 \pm 0,612$ \\
$\mathrm{~T}_{8}$ & $10,2 \pm 4,22 \#$ & $3,31 \pm 0,521 \#$ \\
$\mathrm{~T}_{8}+[\mathrm{cPt}] \mathrm{sln}$ & $27,2 \pm 3,68 \#$ & $8,91 \pm 0,231 \#$ \\
\hline
\end{tabular}

Примітка: ${ }^{*}-\mathrm{P}<0,05$ порівняно $3 \mathrm{~T}_{8}+[\mathrm{cPt}] \operatorname{sln} ; \#-\mathrm{P}<0,05$ порівняно 3 контролем.

За введення цисплатину активність ЛДГ збільшилась в 1,3 раза порівняно з контролем. Такий факт вказує на локалізоване ушкодження дистального відділу нефрону метаболітами цього цитостатика.

Маркер цілісності проксимального відділу нефрону - ГТП. У групі $\mathrm{T}_{8}$ ïi активність у сечі збільшилась в 3,7 раза, а за введення цисплатину активність ГТП збільшилась в 9,9 раза порівняно 3 контролем, що вказує на деструкцію канальцевого епітелію в цьому відділі нефрону. За розвитку пухлини відбулось зростання вмісту позитивно заряджених електролітів (катіонів) у сироватці крові. Концентрація калію в групі $\mathrm{T}_{8}$ збільшилась в 1,7 раза порівняно 3 контролем (табл. 4).

\section{Таблиця 4}

Вміст катіонів у крові щурів із пухлиною у щурів, чутливою до дії цисплатину $(\mathrm{n}=8)$

\begin{tabular}{lccc}
\hline Групи тварин & Калій, ммоль/л & Натрій, ммоль/л & Хлориди, ммоль/л \\
\hline Контроль & $5,35 \pm 0,211$ & $196,8 \pm 9,38$ & $107,1 \pm 71,40$ \\
$\mathrm{~T}_{8}$ & $9,33 \pm 1,460 \#$ & $150,1 \pm 39,30$ & $155,9 \pm 8,54$ \\
$\mathrm{~T}_{8}+[\mathrm{cPt}] \mathrm{sln}$ & $12,10 \pm 0,731 \#$ & $31,2 \pm 6,25 \#$ & $153,6 \pm 4,02$ \\
\hline
\end{tabular}

Примітка: * - $\mathrm{P}<0,05$ порівняно з $\mathrm{T}_{8}+[\mathrm{cPt}] \mathrm{sln}$; \# - $\mathrm{P}<0,05$ порівняно 3 контролем.

За умов уведення цисплатину концентрація калію збільшилась у 2,2 раза порівняно з контролем, що може бути наслідком зменшення екскреції цього електроліту через порушення реабсорбції електролітів у канальцях. У групі $\mathrm{T}_{8}$ спостерігали зниження на $30 \%$ вмісту натрію в сироватці, тоді як за введення цисплатину його концентрація знижувалась в 6,3 раза порівняно $з$ контрольними значеннями. Зменшення концентрації натрію на фоні зниження швидкості сечоутворення у щурів, яким уводили цисплатин, може свідчити про затримання води в організмі, гіперволіємію як характерну ознаку цисплатинової інтоксикації. За розвитку пухлини та введення цисплатину збільшувалися концентрації хлоридів у сироватці в 1,4 раза порівняно 3 контролем, що може бути наслідком метаболічного ацидозу, а також затримання іонів $\mathrm{H}^{+}$і хлоридів в організмі дослідних тварин.

Під час визначення концентрації калію в сечі встановлено, що в групі $\mathrm{T}_{8}$ його концентрація зменшилась в 1,9 раза порівняно 3 контролем (табл. 5).

\section{Таблиця 5}

Електролітичний склад сечі у щурів із карциномою, чутливою до дії цисплатину $(\mathrm{n}=8)$

\begin{tabular}{lccc}
\hline Групи тварин & Калій, ммоль/л & Натрій, ммоль/л & Хлориди, ммоль/л \\
\hline Контроль & $5,51 \pm 0,501$ & $0,412 \pm 0,052$ & $535,7 \pm 41,8$ \\
$\mathrm{~T}_{8}$ & $2,92 \pm 0,724 \#$ & $0,102 \pm 0,011 \#$ & $53,6 \pm 1,5 \#$ \\
$\mathrm{~T}_{8}+[\mathrm{cPt}] \mathrm{sln}$ & $35,20 \pm 9,230 \#$ & $0,082 \pm 0,012 \#$ & $455,4 \pm 5,1$ \\
\hline
\end{tabular}

Примітка: \# - $\mathrm{P}<0,05$ порівняно $з$ контролем; * - $\mathrm{P}<0,05$ порівняно ${ }_{3} \mathrm{~T}_{8}+[\mathrm{cPt}] \sin$.

За введення цисплатину концентрація калію в сечі збільшилась у 6,4 раза порівняно з контролем, що вказує на виражену гіперкаліурію як наслідок деструктивних змін у нефроні.

Функціональні зміни нирок за розвитку пухлини супроводжувались порушенням електролітного складу крові та сечі. Пухлинний ріст спричинював розвиток гіпокаліємії, гіпонат- 
ріємії та гіпохлоремії, що виступало однією з головних і ранніх ознак гострої ниркової недостатності. Особливу увагу слід звернути на втрату іонів натрію в крові, що зазвичай супроводжується зменшенням об'єму позаклітинної рідини та плазми, зменшенням артеріального тиску та клубочкової фільтрації, навіть за достатнього надходження рідини розвивається дегідратація. Ці результати співвідносяться 3 наведеними даними дослідження хвилинного діурезу та кліренсу креатиніну.

За дефіциту натрію знижується осмотичний тиск у клітинах, посилюється розпад клітинних білків, збільшується залишковий азот. За введення цисплатину зміни мали інший характер: відмічалась гіперкаліємія, гіпонатріємія та гіперхлоремія, що може свідчити про розвиток ацидозу та серйозні пошкодження клітин організму (нормальних і злоякісних).

Істотну загальну токсичність і нефротоксичність препаратів цисплатину підтверджено та доведено в модельних експериментах із застосуванням клітин карциноми Герена, чутливої до лікування цисплатином (Mandic, 2003). Спостерігали генералізовані порушення функціонування як нирок, так i організму щурів у цілому, що могло становити суттєву загрозу життю тварин (Kapoor, 2001).

Модельна система подібного роду виявилася помітно зручнішим інструментом для дослідження впливу різних агентів із потенційною протипухлинною активністю на гомеостаз живих організмів, зокрема щурів (Hartinger, 2009). Такі експериментальні підходи доцільно застосовувати під час вивчення біохімічних механізмів дії майбутніх антиканцерогенних лікарських засобів на стадії їх розроблення (Kelland, 2007; Dougan, 2008).

Нефротоксичність протипухлинних препаратів беззаперечно становить важливу проблему під час терапії таких захворювань (Benoit, 2005). Для подолання таких складностей в онкологічній практиці потрібно зважати на оцінку процесів функціонування нирок під час лікування цисплатином та іншими подібними лікарськими засобами (Heffeter, 2011). Постійний моніторинг гомеостазу крові та нирок має бути протокольним етапом в антиканцерогенній терапії. У відповідь на встановлені пошкодження роботи нирок слід обов'язково застосовувати нефропротекторні лікарські засоби. Дане дослідження допомагає зрозуміти біохімічні механізми метаболізму лікарських препаратів (Heffeter, 2011) і загалом ксенобіотичних сполук у процесах обміну речовин живих істот.

\section{Висновки}

За умов розвитку пухлини та ін'єкцій цисплатину щурампухлиноносіям спостерігали зниження хвилинного діурезу на $20-60 \%$, кліренсу креатиніну - на 50-70\% та відносної реабсорбції води в ниркових канальцях - на $26 \%$ порівняно 3 контролем. Такі зміни свідчили про порушення концентраційної та вивідної функцій нирок, що вказувало на початок розвитку гострої ниркової недостатності. Як наслідок, у цих щурів визначали гіперкаліємію, гіпонатріємію та гіпохлоремію, що свідчило про розвиток ацидозу та цитолізу. За таких умов відбувалося зменшення об'єму циркулюючої плазми та збільшення концентрації загального білка в крові з одночасним посиленим його виведенням із сечею.

Отримані результати підтвердили, що розвиток карциноми Герена $\mathrm{T}_{8}$ та введення цисплатину зумовлювали пошкодження нирок щурів, а також викликали зміни біохімічних показників, електролітичного складу крові щурів. Такі дані безпосередньо вказують на нефротоксичність цисплатину, що обов'язково необхідно враховувати під час проведення терапевтичних заходів із залученням даного препарату.

\section{References}

Bazaev, V. V., \& Dutov, V. V. (2013). Intsidental renal cell carcinoma: Clinical and morphological features. Urology, 2, 66-68.

Benoit, D. D., Depuydt, P. O., Vandewoude, K. H., Offner, F. C., Boterberg, T., De Cock, C. A., Noens, L. A., Janssens, A. M., \& Decruyenaere, J. M. (2005). Outcome in critically ill medical patients treated with renal replacement therapy for acute renal failure: Comparison between patients with and those without haematological malignancies. Nephrology Dialysis Transplantation, 20, 552-558.

Berkhin, E. B. (1972). Methods of experimental study of the kidneys and water-salt metabolism. Prince Publishing House, Ivanovo (in Russian).

Darmon, M., Ciroldi, M., Thiery, G., Schlemmer, B., \& Azoulay, E. (2006). Clinical review: Specific aspects of acute renal failure in cancer patients. Critical Care, 10, 211-218.

Darmon, M., Thiery, G., Ciroldi, M., de Miranda, S., Galicier, L., Raffoux, E., Le Gall, J. R., Schlemmer, B., \& Azoulay, E. (2005). Intensive care in patients with newly diagnosed malignancies and a need for cancer chemotherapy. Critical Care Medicine, 33, 2488-2493.

Davidson, M. B., Thakkar, S., Hix, J. K., Bhandarkar, N. D., Wong, A., \& Schreiber, M. J. (2004). Pathophysiology, clinical consequences, and treatment of tumor lysis syndrome. American Journal of Medicine, 116, 546-554.

Dougan, S. J., Habtemariam, A., McHale, S. E., Parsons, S., \& Sadler, P. J. (2008). Catalytic organometallic anticancer complexes. Proceding of National Academy of Sciences, 105, 28-33.

Fink, D., \& Howell, S. B. (2000). How does cis-platin kill cells? In: Platinum-based drugs in cancer therapy. Humana Press., Totowa, New Jersey, 149-167.

Han, W. K. (2008). Biomarkers for early detection of acute kidney injury. Nephrology Rounds, 4, 304-309.

Hartinger, C. G., \& Dyson, P. J. (2009). Bioorganometallic chemistry from teaching paradigms to medicinal applications. Chemical Society Reviews, 38, 391-401.

Heffeter, P. (2011). Anticancer activity of metal complexes: Involvement of redox processes. Antioxidants and Redox Signaling, 15(4), 85-127.

Huphreys, B. D., Soiffer, R. J., \& Magee, C. C. (2005). Renal failure associated with cancer and its treatment: And update. Journal of the American Society of Nephrology, 4, 151-161.

Johnson, R. J., Kivlighn, S. D., Kim, Y. G., Suga, S., \& Fogo, A. B. (1999). Reappraisal of the pathogenesis and consequences of hyperuricemia in hypertension, cardiovascular disease, and renal disease. American Journal of Kidney Diseases, 33, 225-234.

Kapoor, M., \& Chan, G. Z. (2001). Malignancy and renal disease. Critical Care Clinics, 17, 571-598.

Kelland, L. (2007). The resurgence of platinum-based cancer chemotherapy. Nature Reviews Cancer, 11, 573-584.

Lee, M. S. (2012). Systematic prioritization of cancer combination therapies: Are we really on target. Future Medicinal Chemistry, 2, 387-389.

Loh, A. H. L., \& Cohen, A. H. (2009). Drug-induced kidney disease pathology and current concepts. Annals. Academy of Medicine, Singapore, 38(3), 240-250.

Mandic, A., Hansson, J., Linder, S., \& Shoshan, M. C. (2003). Cis-platin induces endoplasmic reticulum stress and nucleus-independent apoptotic signaling. The Journal of Biological Chemistry, 9, 100-106.

Martins, N. M., Santos, N. A., Curti, C., Bianchi, M. L., \& Santos, A. C. (2008). Cis-platin induces mitochondrial oxidative stress with resultant energetic metabolism impairment, membrane rigidification and apoptosis in rat liver. Journal of Applied Toxicology, 7, 337-344.

Moreli, J. E., Thomas, D. R., \& Wilson, M. (2006). Cachexia: Pathophysiology and clinical relevance. American Journal of Clinical Nutrition, 83, 735-743.

Moskvina, L. V., Andreeva, Y. Y., \& Malkov, P. G. (2013). Clinically significant morphological parameters of renal cell carcinoma. Oncology, 4, 34-39.

Nosov, D. A. (2012). Disseminated renal cell carcinoma: Current capabilities of drug treatment. Practical Oncology, 15(3), 185-195.

Pal, S., Sadhu, A. S., Patra, S., \& Mukherjea, K. (2008). Histological vis-avis biochemical assessment on the toxic level and antineoplastic efficacy of a synthetic drug Pt-ATP on experimental animal models. Journal of Experimental and Clinical Cancer Research, 68, 98-112. 